\title{
NUMERICAL STUDY ON THE EFFECT OF DIESEL ENGINE EMISSIONS BY CONTROLLING WATER INJECTION THROUGH THE EXHAUST MANIFOLD
}

\section{SHESHANTH BONTHI ${ }^{1} \&$ D. SENTHIL KUMAR ${ }^{2 *}$}

${ }^{1} P G$ Student, Department of Mechanical Engineering, Amrita School of Engineering, Amrita Vishwa Vidyapeetham, Coimbatore, India

${ }^{2}$ Assistant Professor, Department of Mechanical Engineering, Amrita School of Engineering, Amrita Vishwa Vidyapeetham, Coimbatore, India

\begin{abstract}
$\mathrm{NO}_{x}$ and soot emissions have become an important concern for diesel engine due to the stringent emission standards and also due to the trade-off characteristics between them. Water injection is one of the efficient methods to reduce $\mathrm{NO}_{x}$ and soot emissions withbetter trade-off. A computational study is conducted to investigate the $\mathrm{NO}_{x}$ and soot emissions when water is injected through exhaust manifold in a single-cylinder DI diesel engine. The simulations are conducted for two casesi.) Water injection in the exhaust manifold when the exhaust valve is open ii.) Water injection in the exhaust manifold when the exhaust valve is reopened during suction stroke. These simulations are carried out for threewater injection quantities $6 \mathbf{m g}, 16 m g$ and $24 m g$. The water injection could reduce $\mathrm{NO}_{x}$ emissions with better $\mathrm{NO}_{x}$ and soot trade-off, due to the thermal, dilution and chemical effects. The water injection throughexhaust manifold strategy utilizes the exhaust gas heat to vaporize the water molecules and also createsan internal EGR effect. Results indicated that the $\mathrm{NO}_{x}$ is reduced by about $73-75 \%$ when $16 \mathrm{mg}$ of water is injected. At this water quantity, it is also observed that the $\mathrm{NO}_{x}$ and soot trade-off is less. In addition,as the water quantity increases the difference in $\mathrm{NO}_{x}$ and soot emission values of the two cases are getting narrowed.

KEYWORDS: Diesel Engine, Water Injection, Exhaust Manifold, No Reduction, CFD
\end{abstract}

Received: Jun 10, 2020; Accepted: Jun 30, 2020; Published: Aug 01, 2020; Paper Id.: IJMPERDJUN2020562

\section{INTRODUCTION}

Engines are the energy generating source for most of the automobiles and many industrial applications. Engines use fossil fuel as the working fluid, which makes them to be the major concern for environmental pollution. Due to the increase in vehicle population, the emission has becomea severe problem. Reduction of engine emissions has become the reason for the implementation of the emission standards. Many kinds of researches are going on for the reduction of engine emissions. Among diesel engine emissions, $\mathrm{NO}_{\mathrm{x}}$ and soot emissions are more concerned than $\mathrm{HC}$ and $\mathrm{CO}$ emissions, since $\mathrm{HC}$ and $\mathrm{CO}$ emissions are very less compared to $\mathrm{NO}_{\mathrm{x}}$ and soot. $\mathrm{NO}_{\mathrm{x}}$ formation mechanism is based on the Zeldovich equations [1]. The rise in the cylinder pressure leads to high temperature in the combustion process, at these high temperatures, diatomic nitrogen molecules break into monatomic nitrogen molecule and then oxidises to form NO. The NO generated in the post flame gases are more than NO generated at the flame front.The $\mathrm{NO}_{\mathrm{x}}$ and soot emissions have a trade-off with each other which makes it hard to reduce both of them simultaneously. Soot is the carbonaceous matter that is formed due to unburnt hydrocarbons and some lubricant oil traces. For $\mathrm{NO}_{\mathrm{x}}$ and soot reduction there are many strategieslike altering fuel injection, changing 
compression ratio, exhaust gas recirculation, water introduction into the combustion chamber, after treatment systems etc.

Water introduction is one the strategy which reduces the $\mathrm{NO}_{\mathrm{x}}$ and soot emissions with less trade-off difference. When water is introduced into the cylinder it creates three effects thermal, dilution and chemical effects on the combustion which contributes to $\mathrm{NO}_{\mathrm{x}}$ and soot reduction. The thermal effect leads to the absorption of latent heat present in the chamber by the water molecules, this tends to the decreased flame temperature which helps in reducing the $\mathrm{NO}_{\mathrm{x}}$ emissions [2][9]. In dilution effect, due to the presence of water molecules in a combustion mixture will decrease the availability of oxygen,whichleads to increase in mixing rate of fuel and air, thus the mass fraction of fuel that burns under premixed condition also increases [3][9][10]. This leads to less $\mathrm{NO}_{\mathrm{x}}$ and soot formation. In chemical effect, the water introduction into the cylinder leads to the increase in $\mathrm{OH}$ radicals, which effects the soot oxidation and reduce the soot formation[3][4].

Water introduction into the cylinder can be done in three ways water-diesel emulsion, direct water injection and water injection through the manifold. Water-diesel emulsion generally composes of diesel, water and an emulsifier which is injected as the fuel into the cylinder. But this technique requires a separate emulsifier to blend water and diesel, which complicates in the fuel economy and performance. Direct water injection is a technique in which the water is injected from the fuel injector with two individual holes or by a separate injector for water injection. In this technique, water injection timing can be varied. But this technique leads to the design complication for engine and fuel injector. Water injection through the manifold is a better and feasible technique for water introduction into the cylinder. In this water injection through the intake manifold is a well-known strategy, in which water is injected through the intake manifold.

G. Greeves, I. M. Khan and G. Onion [3] conducted experiments on water introduction into the cylinder to observe the effect on emission and combustion of a diesel engine. The experiments were conducted on water injection in inlet manifold, direct water injection into the cylinder and water-fuel emulsion injection into cylinder. It is observed that because of water addition into the chamber, NOx is reduced up to $70 \%$. Besides, it can reduce CO and smoke up to $50 \%$. Masahiro Ishida, H. Ueki and D. Sakaguchi [6] examined theoretically and experimentally the NO formation when water is injected at inlet ports. The water quantities of $0.01,0.02$ and $0.03 \mathrm{~kg}$ of water per every $1 \mathrm{~kg}$ mass of air injected into inlet ports where analysed. A huge reduction in NOx emission about $50 \%$ is observed when $0.03 \mathrm{~kg}$ of water per every $1 \mathrm{~kg}$ mass of air is injected in the ports.

Xiaokang Ma, F. Zhang, K. Han, Z. Zhu and Y. Liu [7] studied on emission and combustion effects due to water injection into the manifold. The investigation was based on CFD analysis on intake manifold water injection. The study concludes that water injection reduces the in-cylinder mean pressure and temperature, which leads to longer ignition delay. This further tends to a huge decrease in NOx and Soot emissions. It is also observed that when compared to the thermal effect, dilution effect and chemical effect, the dilution effect caused by water injection in intake manifold plays an important role in engine combustion and emissions.F. Bedford, C. Rutland, P. Dittrich, A. Raab and F. Wirbeleit [2] conducted CFD analysis on direct water injection to observe the emission and combustion parameters. The water injection was modelled with advancing the injection timing. It is observed that there is a significant decrease in NOx, particulate matter and specific fuel consumption. It is also observed that more the water injection can increase the injected liquid volume up to the point where the injection duration is long. This leads to an increase in soot emissions.

M.Nour, H. Kosaka, A. K. Abdel-Rahman and M. Bady [5] conducted experiments on water injection through the exhaust manifold. The emission and combustion effects due to the water injection quantities of $6,12,24 \mathrm{and} 40 \mathrm{mg} / \mathrm{cycle}$ in the exhaust manifold was observed and compared with the effects due to EGR. It was observed that the water injection 
can increase the indicated mean effective pressure up to $11 \%$, reduction NOx up to $45 \%$ and decrease in soot when compared to EGR. It is also observed that the combined EGR and water injection strategy could reduce the NOx and PM trade-off.M.Farag, H. Kosaka, M. Bady and A. K. Abdel-Rahman [8] experimented on intake manifold water injection and exhaust manifold water injection with $40 \mathrm{mg} / \mathrm{cycle}$ water quantity. The emission and combustion parameters were compared in both cases and observed that the intake manifold water injection reduces NOx emissions up to $88 \%$, whereas the exhaust manifold water injection improves engine performance while reducing NOx and soot emissions.

From these researches, it can be observed that water injection will reduce NOx and soot emissions. In addition, when utilized with EGR there is a slight reduction in the performance. This could be overcome by using water injection through the exhaust manifold. This technique also helps to recover the exhaust waste heat. The present work is based on the water injection through exhaust manifold by water injectionwhenthe exhaust valve is opened and water injection whenthe exhaust valve is reopened in suction stroke. This technique utilizes exhaust gas heat to vaporize the water molecules. Due to the exhaust valve is open, the injected water enters into the cylinder with some amount of exhaust gas. This gives the additional benefit of the internal Exhaust Gas Recirculation (EGR). The main objective of this work is to reduce the $\mathrm{NO}_{\mathrm{x}}$ emission with less $\mathrm{NO}_{\mathrm{x}}$ and soot trade-off using water injection through the exhaust manifold. The present work is concentrated on the computational study of the $\mathrm{NO}_{\mathrm{x}}$ and soot behaviour whenwater is injected through the exhaust manifold.

\section{METHODOLOGY}

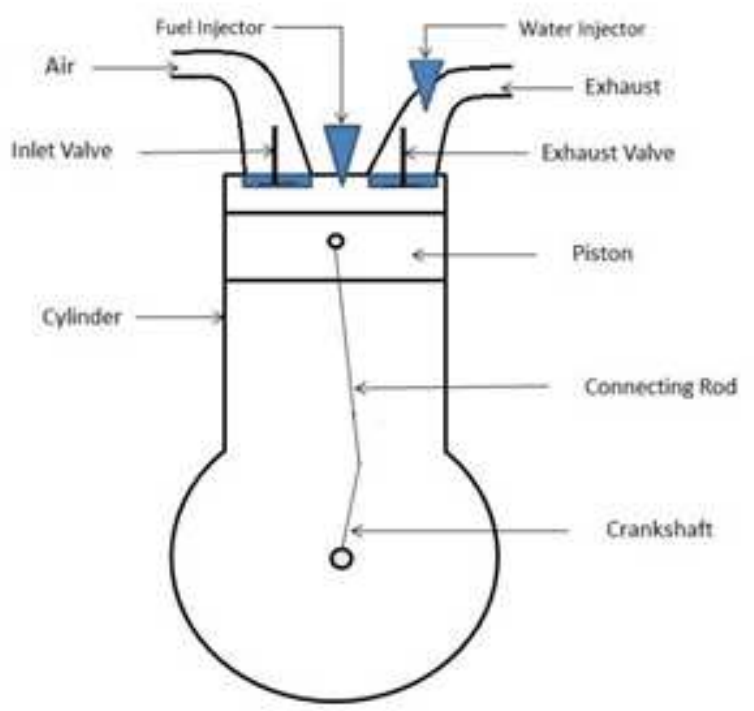

Figure 1: Schematic Diagram of the Setup 


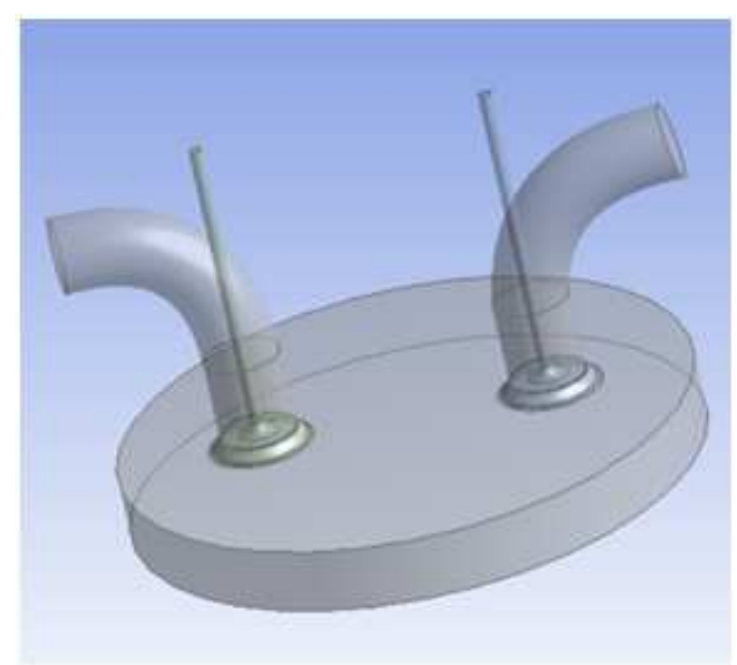

Figure 2: Engine Geometry

Simulations are conducted on a four-stroke single-cylinder direct injection CI engine, with the engine specifications as shown in tables 1 to 3 . The schematic diagram for the simulation of water injection through exhaust manifold setup is shown in figure 1. The geometry of the engine is modelled in SolidWorks designing software, as shown in figure 2. Meshing and Simulationsare carried out in ANSYS. For this simulation,the ANSYS IC Engine (Fluent) is utilized, since this module can generate the dynamic simulation by usingthe inbuilt solver algorithm. The model used for the simulation is a standard k-epsilon model with $\mathrm{NO}_{\mathrm{x}}$ and soot enabled. The soot model used is Moss-Brookes model. The simulation is run with engine speed $1800 \mathrm{rpm}, 2.45 \mathrm{bar}$ and $333 \mathrm{~K}$ initial conditions. The surface temperature of the piston, cylinder head and cylinder walls are estimated to be $560 \mathrm{~K}, 480 \mathrm{~K}$ and $440 \mathrm{~K}$ respectively as boundary conditions.

Table 1: Engine Specification

\begin{tabular}{|l|l|}
\hline \multicolumn{1}{|c|}{ Parameter } & \multicolumn{1}{c|}{ Specification } \\
\hline Bore & $89 \mathrm{~mm}$ \\
\hline Stroke & $100 \mathrm{~mm}$ \\
\hline Displacement & $622 \mathrm{cc}$ \\
\hline Compression ratio & $15: 1$ \\
\hline Engine Type & 4 stroke single cylinder CI engine \\
\hline Fuel & Diesel \\
\hline Crank Radius & $45 \mathrm{~mm}$ \\
\hline Connecting Rod Length & $144.3 \mathrm{~mm}$ \\
\hline
\end{tabular}

Table 2: Valve Timing

\begin{tabular}{|l|l|}
\hline \multicolumn{1}{|c|}{ Parameter } & \multicolumn{1}{c|}{ Specification } \\
\hline Intake Valve - IVO, IVC & $14 \square$ BTDC, 30 $\square$ ABDC \\
\hline Exhaust Valve - EVO, EVC & $39 \square$ BBDC, 5 $\square$ ATDC \\
\hline Exhaust Valve ReOpening & $20 \square$ ATDC \\
\hline Exhaust Valve ReClosing & $60 \square$ ATDC / 60 $\square$ \\
\hline
\end{tabular}


Table 3: Fuel and Water Injection Specifications

\begin{tabular}{|l|l|}
\hline \multicolumn{1}{|c|}{ Parameter } & \multicolumn{1}{c|}{ Fuel Injection } \\
\hline Fuel Quantity & $32 \mathrm{mg}$ \\
\hline Fuel Injection Timing & $8 \square$ BTDC / 352 $\square$ \\
\hline Fuel Injection Duration & $26 \square$ crank angle \\
\hline \multicolumn{2}{|c|}{ Water Injection } \\
\hline Water Injection Quantity & $6 \mathrm{mg}, 16 \mathrm{mg}$ and 24 mg \\
\hline Injection Timing (WI @ Exhaust Valve opened) & $12 \square$ BTDC / -12 $\square$ \\
\hline Injection Timing (WI @ Exhaust Valve Reopened) & $40 \square$ ATDC / 40 $\square$ \\
\hline Injection Duration & $16 \square$ crank angle \\
\hline
\end{tabular}

\section{RESULTS AND DISCUSSIONS}

The simulations for the water injection through exhaust manifold are conducted with two cases i) Water injection when the exhaust valve is open and ii) Water injection when the exhaust valve is reopened in the suction stroke. The results are then compared with the normal combustion simulation results.

\subsection{Water Injection when the Exhaust Valve is Open}

In this case, the water is injected between the time when the exhaust valve and intake valve both are open, $12 \square$ BTDC at the suction stroke. Three simulations are conducted in this case with different water injection quantities of $6 \mathrm{mg}, 16 \mathrm{mg}$ and 24mg. In these three simulations, the $\mathrm{NO}_{\mathrm{x}}$ and soot parameters are monitored and plotted in figures $3(\mathrm{a})$ and $3(\mathrm{~b})$. $\mathrm{The} \mathrm{NO}_{\mathrm{x}}$ and soot emission behaviour can be observed through these plots.

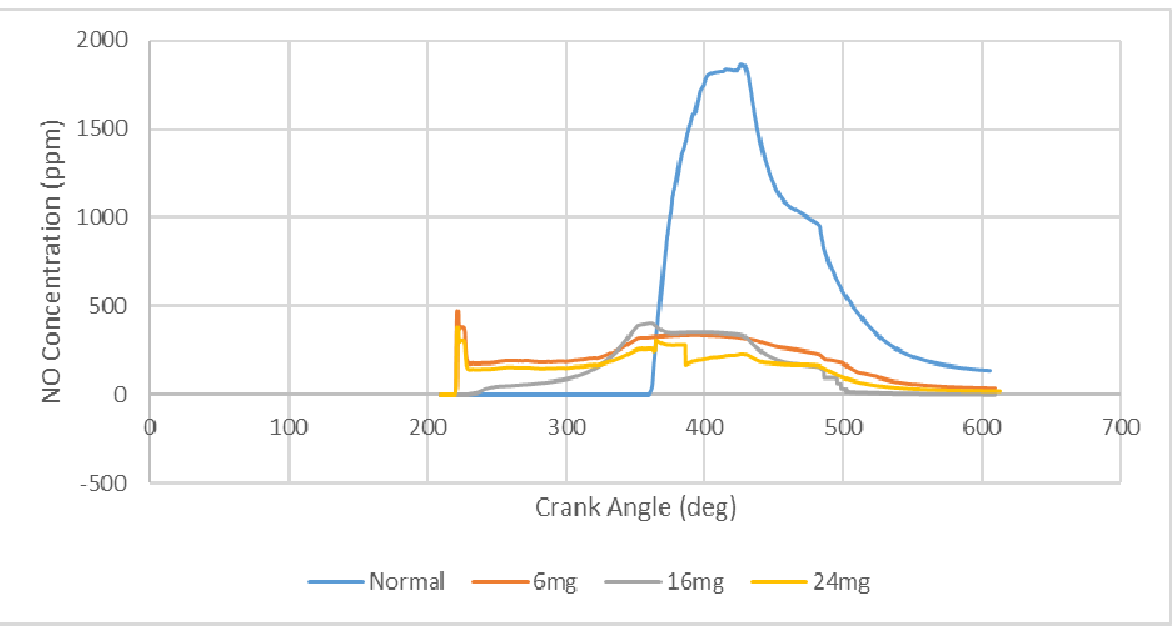

Figure 3(a): NOEmission for WI@EVO 


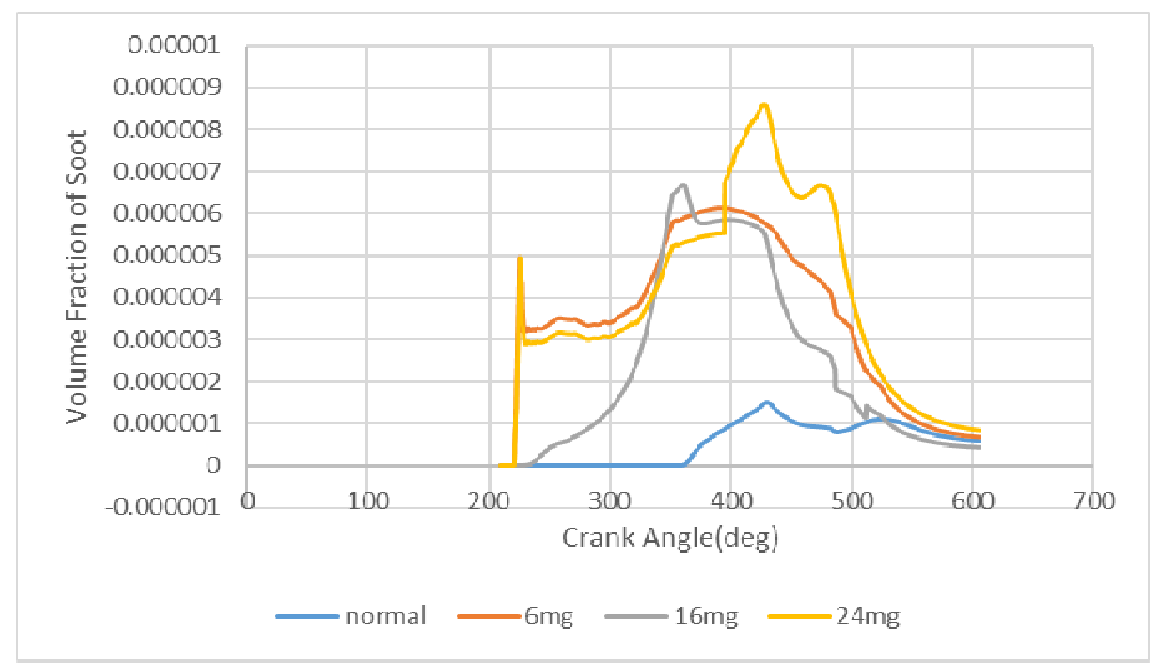

Figure 3(b): Soot Emission for WI@EVO

Due to the water injection, the $\mathrm{NO}_{\mathrm{x}}$ is reduced by about $73 \%$ than the normal combustion. But when it comes to the soot emission a drastic increase is observed, this is due to the trade-off between $\mathrm{NO}_{\mathrm{x}}$ and soot. When the average of these plots is taken and compared, it is observed that as the water quantity increases the $\mathrm{NO}_{\mathrm{x}}$ values decreases, but whereas soot behaviour is not linear. This can be seen in figure 4. Among the three water quantities, $16 \mathrm{mg}$ of water injection has a less trade-off, since it has less soot value with almost less $\mathrm{NO}_{\mathrm{x}}$ value. Thus, the less trade-off for the $\mathrm{NO}_{\mathrm{x}}$ and soot emissions can be near to the $16 \mathrm{mg}$ of water injection in this study.

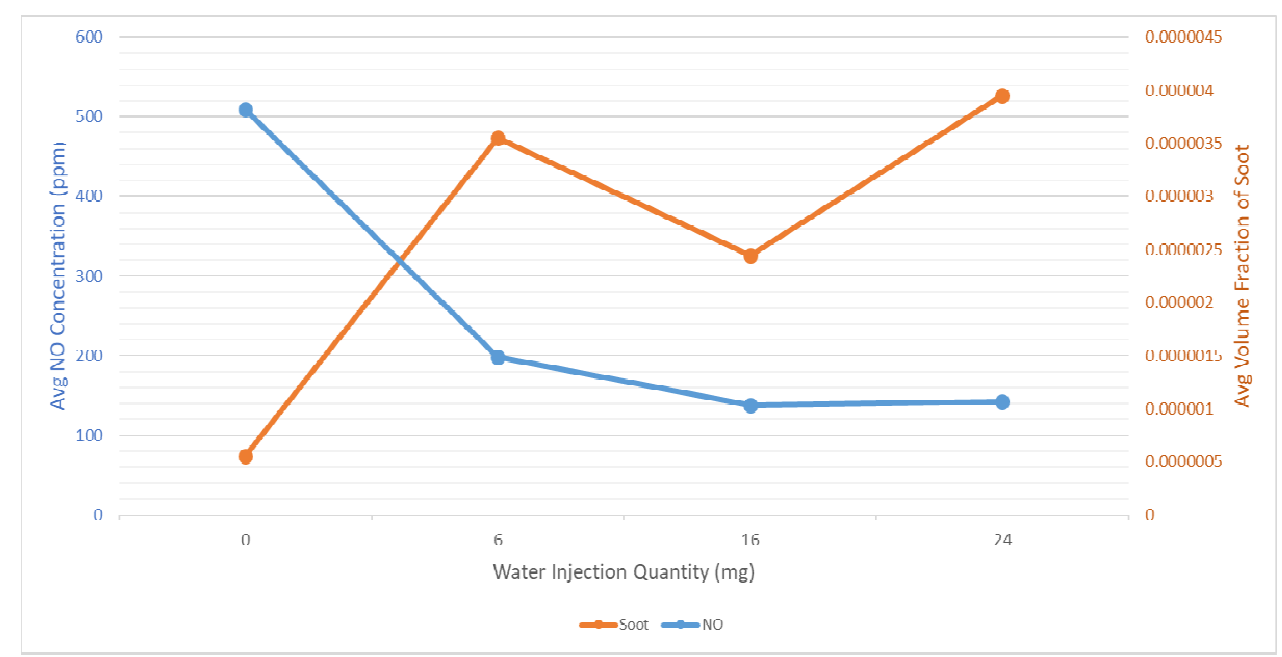

Figure 4: Average NO $_{x}$ and Soot Plot for WI@EVO

\subsection{Water Injection when the ExhaustValve is Reopened}

In this case, the water is injected when the exhaust valve is reopened during suction stroke. The exhaust valve is reopened, so that the water can be injected at a different timing. This strategy gives the feasibility for finding the optimal injection timing when water is injected through the exhaust manifold. But this work is only conducted on single water injection timing when the exhaust valve is reopened at $40 \square$ ATDC in suction stroke. The three simulations with $6 \mathrm{mg}, 16 \mathrm{mg}$ and $24 \mathrm{mg}$ of water injection are conducted and plotted in figures5(a) and 5(b). The $\mathrm{NO}_{\mathrm{x}}$ and soot behaviour are similar to the previous case but with different values. 


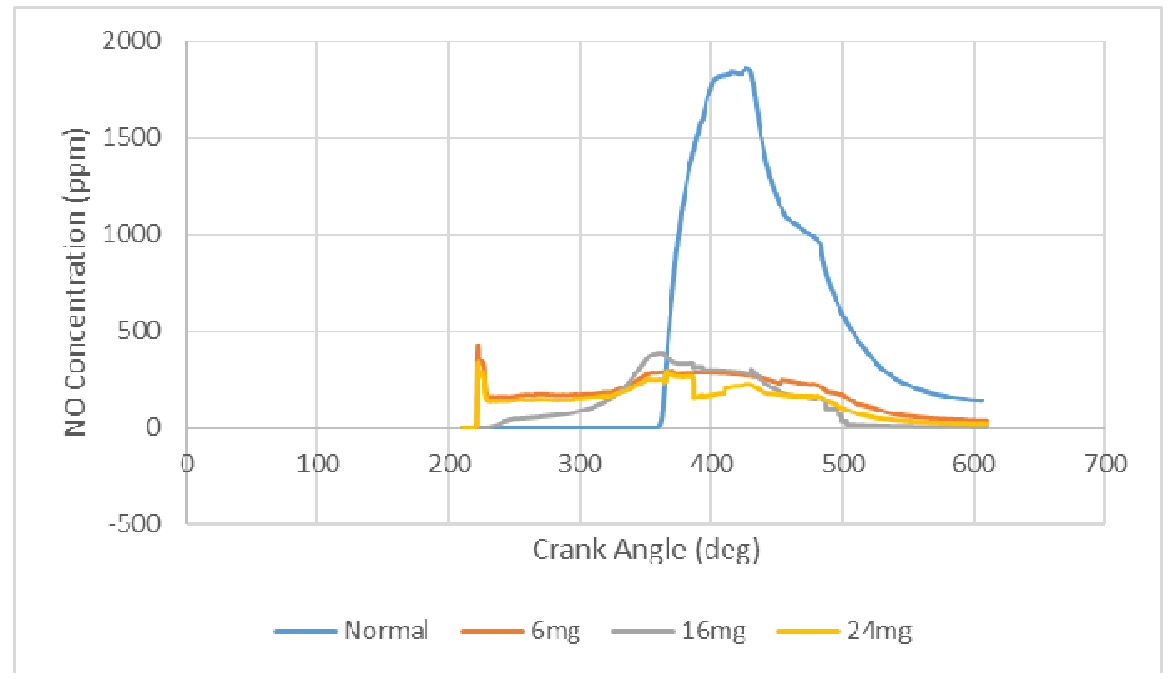

Figure 5(a): NOxEmission for WI@EVRO

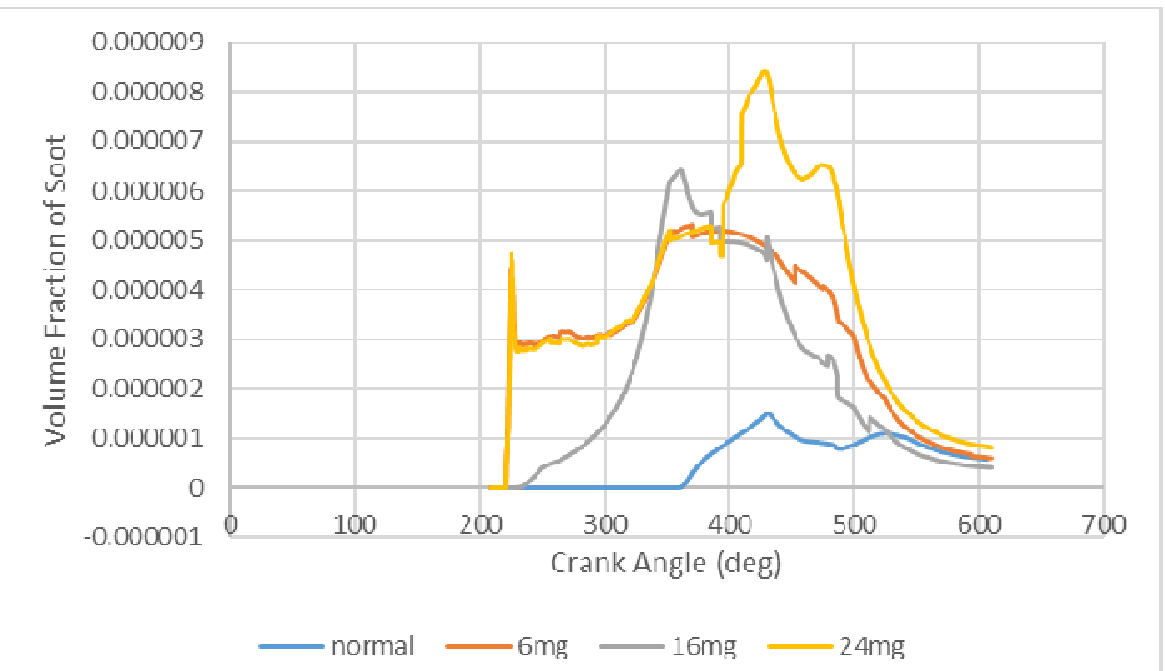

Figure 5(b): Soot Emission for WI@EVRO

Due to the water injection, the $\mathrm{NO}_{\mathrm{x}}$ is reduced by about $75 \%$ than the normal combustion. But when it comes to the soot emission a drastic increase is observed, this is due to the trade-off between $\mathrm{NO}_{\mathrm{x}}$ and soot. When the average of these plots is taken and compared as shown in figure 6, it is observed that as the water quantity increases the $\mathrm{NO}_{\mathrm{x}}$ values decreases, but whereas soot behaviour is not linear. Among the three water quantities, $16 \mathrm{mg}$ of water injection has a less trade-off, since it has less soot value with almost less $\mathrm{NO}_{\mathrm{x}}$ value. Thus, the less trade-off for the $\mathrm{NO}_{\mathrm{x}}$ and soot emissions can be near to the $16 \mathrm{mg}$ of water injection in this study. This case also has the same behaviour as the previous one, but the difference in these cases can be seen when they are compared with each other. 


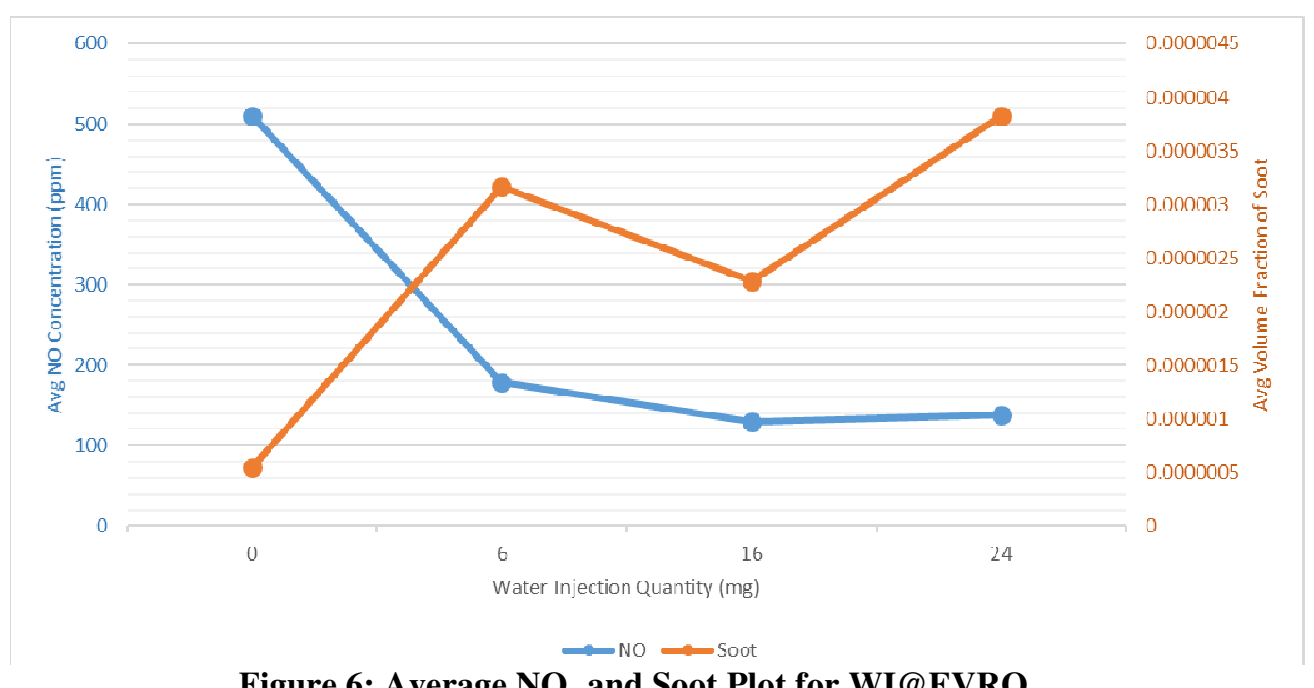

Figure 6: Average $\mathrm{NO}_{\mathrm{x}}$ and Soot Plot for WI@EVRO

Figure 7 is plotted with average values of the $\mathrm{NO}_{\mathrm{x}}$ and soot values from both the cases to observe the difference when the water injection timing is changed. As both cases have similar behaviour with a slight value difference. But the difference in these values is getting narrowed when the water injection quantity is increased. From the comparison of these cases, it is observed that the water injection through the exhaust manifold can reduce the $\mathrm{NO}_{\mathrm{x}}$ emissions about $73-75 \%$ with less trade-off difference when water injection quantity is near $16 \mathrm{mg}$. From the comparison plot, it is also observed that the optimal water quantity can be near to thegreater than or equal to $16 \mathrm{mg}$ since the behaviour is much similar.

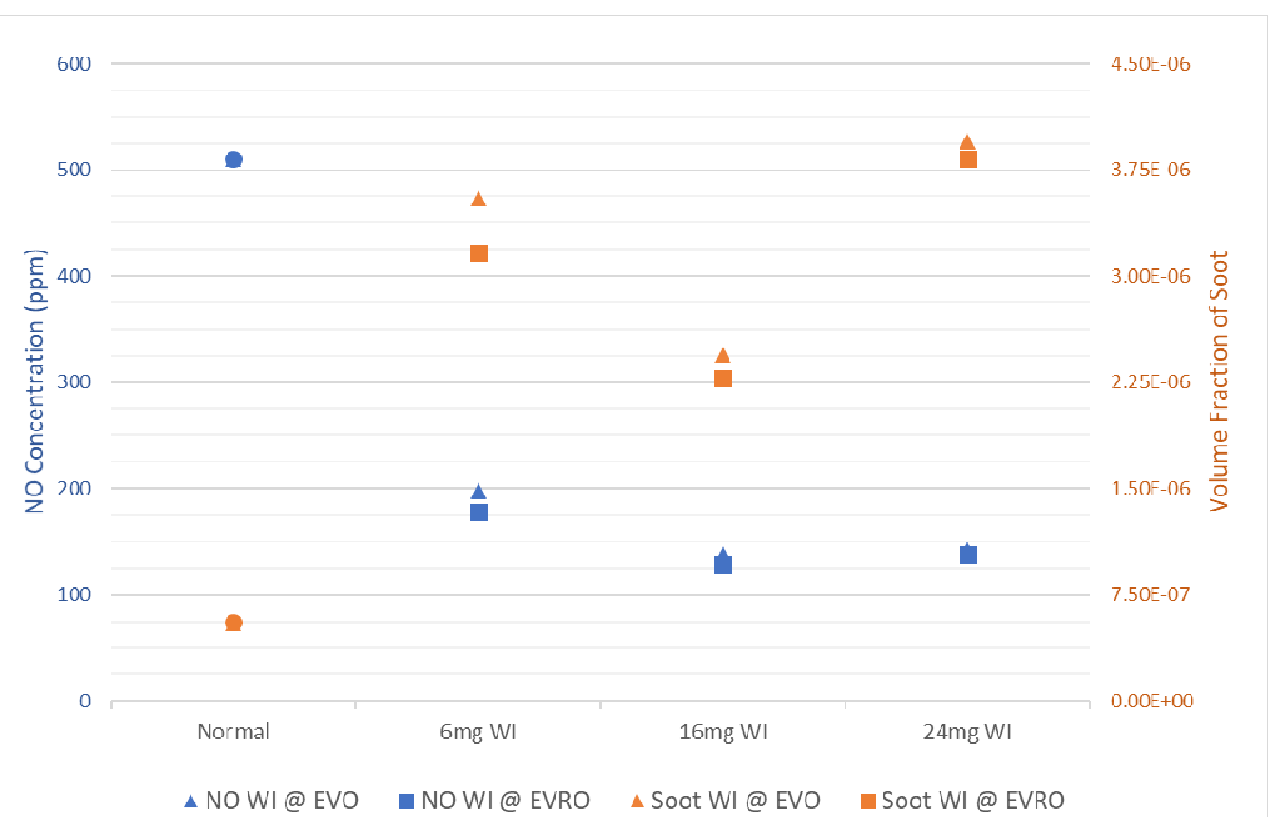

Figure 7: Comparison of Both Cases

\section{CONCLUSIONS}

A computation study is conducted to investigate the $\mathrm{NO}_{\mathrm{x}}$ and soot behaviour when the water is injected through the exhaust manifold in a diesel engine. The simulations are conductedby considering the two cases of water injection when the exhaust valve is open and the exhaust valve is reopened with $6 \mathrm{mg}, 16 \mathrm{mg}$ and $24 \mathrm{mg}$ water injection quantities. From the simulation results of these two cases, it is observed that, 
- $\mathrm{NO}_{\mathrm{x}}$ can be reduced by about $73-75 \%$ with less trade-off difference in the exhaust manifold water injection.

- $16 \mathrm{mg}$ of water injection quantity has the optimal $\mathrm{NO}_{\mathrm{x}}$ and soot emissions behaviour.

- As the water injection quantity increases the emission value difference between both cases comes closer.

- From this study $16 \mathrm{mg}$ of water injection is observed to be the optimal water quantity, but this cannot be assured until the techniqueis studied on other emission and performance characteristics.

\section{REFERENCES}

1. Zeldovich, Y. A., D. Frank-Kamenetskii, and P. Sadovnikov. "Oxidation of nitrogen in combustion." Publishing House of the Acad of Sciences of USSR, 1947.

2. Bedford, F., C. Rutland, P. Dittrich, A. Raab, and F. Wirbeleit. "Effects of Direct Water Injection on DI Diesel Engine Combustion." SAE Technical Papers 2000-01-2938, 2000.

3. Greeves, G., I. M. Khan, and G. Onion. "Effects of Water Introduction on Diesel Engine Combustion and Emissions." Symposium (International) on Combustion 16 (1): 321-336, 1977.

4. Kadota, T \& Yamasaki, H. (2002). "Recent advances in the combustion of water fuel emulsion." Progress in Energy and Combustion Science 28 (5), 385-404, 2002.

5. Nour, M., H. Kosaka, A. K. Abdel-Rahman, and M. Bady. "Effect of Water Injection into Exhaust Manifold on Diesel Engine Combustion and Emissions." Energy Procedia 100 (2016) 178-187, 2016.

6. Ishida, M., H. Ueki, and D. Sakaguchi. "Prediction of NOx Reduction Rate due to Port Water Injection in a Di Diesel Engine.” SAE Technical Papers 972961, 1997.

7. Ma, X., F. Zhang, K. Han, Z. Zhu, and Y. Liu. "Effects of Intake Manifold Water Injection on Combustion and Emissions of Diesel Engine." Energy Procedia 61 (2014) 777-781, 2014.

8. Farag, M., H. Kosaka, M. Bady, and A. K. Abdel-Rahman. "Effects of Intake and Exhaust Manifold Water Injection on Combustion and Emission Characteristics of a DI Diesel Engine." Journal of Thermal Science and Technology 12 (1), 2017.

9. Subramanian KA. "A comparison of water-diesel emulsion and timed injection of water into the intake manifold of a diesel engine for simultaneous control of NO and smoke emissions.” Energy Conversion Management (2011) 52:849-57, 2011.

10. Radloff, Ernst \& Gautier, Charles. (2005). "Diesel Engine NOx Reduction Using Charge Air Water Injection." ASME, Internal Combustion Engine Division Fall Technical Conference (ICEF2005), 11-14, pp. 55-66, 2005.

11. Sagar Patel, Gaurav P Rathod, Tushar M Patel. "Experimental investigation of diesel engine with water injection system on emission parameters." IOSR Journal of Mechanical and Civil Engineering. 2278-1684, p-ISSN: 2320-334X, Volume 11, PP 47-51, 2014.

12. Udayakumar, R., S. Sundaram, and R. Sriram. "Reduction of NOx Emissions by Water Injection into the Inlet Manifold of a Di Diesel Engine.” SAE Technical Papers 2003-01-0264, 2003.

13. S. Sandeep, D. Senthil Kumar, S. Krishnan, S. K. Pandey, "Assessment of Atomized Water Injection in the Intake Manifold of a Heavy Duty Diesel Engine for NOx Reduction Potential" IOP Conf. Series: Materials Science and Engineering 577 (2019)

14. D Senthil Kumar, S Thirumalini and H S S K Praveen," Experimental investigation to improve performance and emission characteristics of a diesel engine by using n-butanol as additive to the biodiesel-diesel blends" IOP Conf. Series: Materials Science and Engineering 577 (2019). 
15. D. Senthil Kumar \& S. Thirumalini (2020): Investigations on effect of split and retarded injection on the performance characteristics of engines with cashew nut shell biodiesel blends, International Journal of Ambient Energy. doi.org/10.1080/01430750.2020.1730961.

16. R. Vishnu Varthan and D. Senthil Kumar, “Emission Characteristics of Turbocharged Single Cylinder Diesel Engine”, Indian Journal of Science and Technology, Vol 9(17), May 2016 